\title{
Research on Innovation and Entrepreneurship Education for College Students in the Internet Era
}

\author{
Han Wei \\ Xi'an Fanyi University, Xi'an, Shaanxi, China, 710105
}

Keywords: Internet era; innovation and entrepreneurship education

\begin{abstract}
It has become a trend for Chinese college students to respond to the national "mass entrepreneurship and innovation" strategy. However, in the Internet age, how to accomplish the education and training of talents through Internet thinking has become an urgent problem to be solved to innovate the professional teaching mode of colleges and universities with Internet thinking. And the rational planning of students' career planning plays an important role in the innovation and entrepreneurship education of college students. Through Internet thinking, a culture of campus characteristic entrepreneurship will be created to expand the way of innovation and entrepreneurship of college students under the Internet thinking, and establish the course model of Internet "tutor band". This paper analyzes the current situation of college students' innovation and entrepreneurship development, and explains the ways to cultivate college students' innovative entrepreneurial consciousness.
\end{abstract}

\section{Introduction}

The era of "Internet plus" is based on the Internet platform, and the time of this era is the integration of various industries through Internet communication technology. Through the integration of industry, the Internet era promotes the upgrading of the whole industry and builds the new ecology of life through the improvement of product technology. In today's Internet age, the Internet has become an indispensable platform and tool for life. College students must master the Internet technology to adapt to the the times' development. College students use the Internet to get opportunities in innovation and entrepreneurship. Chinese university students are engaged in innovation and entrepreneurship activities or innovation and entrepreneurship education through the following ways. For example, the training of college students with Internet service colleges and universities. Through the content of intermediary services, students can be guided to use the Internet platform to engage in innovation and entrepreneurship activities or innovation and entrepreneurship.

\section{Development Status of Innovation and Entrepreneurship Education of College Students}

In the context of the Internet age, it has become an important way and way to use the Internet to engage in innovation and entrepreneurship education. The innovation and entrepreneurship of college students will be greatly influenced by the professional, family environment, interests and hobbies, etc., and the college students still face the problem of capital shortage. But with the popularization of the Internet, Internet technology has become an indispensable way for people to live. And it has become a trend to start a business on the Internet or to innovate and start a business through the Internet. At present, most universities in China have launched the innovation and entrepreneurship education, and the country has held the 10th "challenge cup" China university student entrepreneurship plan competition. This is a sign that innovation and entrepreneurship education is gradually gaining support from college students, and is constantly getting the independent participation of college students. However, there are still some problems in the cultivation of college students. For example, Innovation and entrepreneurship education and Internet have insufficient connection degree, innovation and entrepreneurship campus culture construction does not reflect the Internet thinking. And Internet innovation and entrepreneurship does not expand the Internet thinking. 


\section{Training Path of Innovation and Entrepreneurship of College Students under the Internet Thinking}

\subsection{Introduce Internet thinking of innovation and entrepreneurship into classroom teaching.}

The innovation and entrepreneurship of Internet thinking requires the following contents to be deeply integrated, such as innovation and entrepreneurship theory and practical knowledge, finance and management knowledge and Internet knowledge. Which is a kind of thinking training that requires innovation and entrepreneurship through Internet thinking. This kind of training is not only the training of students' professional skills or practical ability, but also the way of thinking about innovative entrepreneurial students. Which is for students to think about their own innovation and entrepreneurship in the background. In the course of teaching, students must have a good understanding of the business model of the Internet, such as C2C, B2B, B2C, B2D, etc. Only in this way can they start to develop their own Internet thinking. Colleges and universities must pay attention to whether students' innovation and entrepreneurship plans are combined with the current Internet background. The plan is written through Internet thinking. At the same time, we should pay attention to whether the content of this proposal has the analysis of the current situation of the industry and the SWOT of the project, whether it can be counted by means of Internet thinking. Traditional teaching methods should be avoided in the teaching of Internet. The following methods are used to cultivate Internet thinking innovation and entrepreneurship, such as using open case teaching and simulation teaching. And it is possible to stimulate students' enthusiasm for entrepreneurship.

\subsection{Establish characteristic campus culture activities.}

The thought of the Internet is actually the user's thinking, which needs to be considered in the user's perspective. So, in the establishment of innovation and entrepreneurship campus activities, universities should attach importance to the concept of "user-centered" entrepreneurship. We will organize special campus activities by promoting the innovation and entrepreneurship of Internet thinking. Through the following aspects, we cultivate and strengthen the Internet innovation and entrepreneurship awareness. First, hold the innovation and entrepreneurship Internet thinking contest. The competition is through the Internet tools and thinking of playing to innovative entrepreneurial project, one of the important ways including on the current market analysis of the innovative entrepreneurial projects, data processing and data analysis, etc., Through SWOT's concept, this paper expounds the possibility of project operation, which can greatly stimulate students' enthusiasm for innovation and entrepreneurship. Second, hold the Internet innovation and entrepreneurship competition. The way of the game is to create a professional team of students by themselves, and select the entrepreneurial topics selected by the competition to carry out the innovation and entrepreneurship practice mode. The model is a simulated network sales method through Internet, which can train students' innovation and entrepreneurship ability through real entrepreneurship, and stimulate the enthusiasm of innovation and entrepreneurship of college students. Third, hold an Internet innovation and entrepreneurship seminar. Colleges and universities make special lectures to college students by seeking entrepreneurs who are successful in Internet innovation and entrepreneurship, and give them a clear understanding.

\subsection{Students should have innovative and entrepreneurial thinking.}

Under the background of the current Internet era, college students want to innovate and start their own businesses, and they can improve their Internet thinking in the following three ways. First, set up "fan" thinking, which is to establish brand effect. Good market reputation is an important way of product sales. Only by establishing good reputation can we provide help for later operation. So, in the initial stage of innovation and entrepreneurship, it is necessary to cultivate good feelings with "fans" and thus be recognized by more people. Second, flow thinking. In the process of innovation and entrepreneurship, college students must have a clear survey of the traffic sources of the entrepreneurial project, and identify the source of customers and suppliers. It's the traffic that counts, the ability to operate. Third, data thinking. Internet technology has led to the advent of big 
data era, which makes it more convenient for people to obtain market data. So, college students must make full use of Internet information and make statistical analysis of effective information, so that every entrepreneur has a clear understanding of entrepreneurship.

\subsection{College students themselves should be good at exploiting and innovating new business models.}

When college students start to innovate and start their own businesses, most of them will be embarrassed by the shortage of funds. So, the initial innovation and entrepreneurship activities can be carried out through new media network platforms such as taobao, weibo and WeChat. This innovative entrepreneurial activity with the help of Internet platform can be carried out in the following two ways. First, the integration of Internet technology and traditional industries. College students can sell agricultural and sideline products or equipment in the region through e-commerce platforms. And it can also use the Internet technology to build modern intelligent breeding technology, through intelligent management and monitoring of agricultural and sideline products cultivation. Second, Internet public service mode. Through Internet technology, a special platform is established to share education resources, medical resources and other online service platforms. Through this innovation and entrepreneurship program with education and medical treatment, we started our business.

\section{Conclusion}

In the wave of innovation and entrepreneurship under the Internet era, college students are undoubtedly the largest and full of vitality. At the same time, due to the rapid development of the Internet and the characteristics of high technical content and the comprehensive quality of college students. In order to promote the innovation and entrepreneurship of college students, the problem of cultivating innovative talents has been put on the agenda of government work. In the process of education, we will cultivate innovative talents and explore the talent cultivation mode suitable for China's development status, and contribute to our country's rapid emergence as an innovative and entrepreneurial power.

\section{References}

[1] Mickiewicz A, Dallimore J T. A Comparison of Analytical Methods for the Content and Purity of Cefradine. Bulletin- Korean Chemical Society (2008), p. 1185 - 1189

[2] Palich, L. E\&Bagby, D. R. Using congnitive theory to explain entrepreneurial risk-taking: challenging conventional wisdom. Journal of Business Venturing (2010), p. 31-34

[3] Colhns J. Cultural diversity an entrepreneurship; Policy responses to immigrant entrepreneurs in Australia. Entrepreneurship and Regional Development (2013), p. 34-37

[4] Anders Lundstorm, Lois Stevenson. Entrepreneurship policy for the future. Swedish Foundation for small Business Research, Irwin (2013), p. 45-51

[5] Jock Collins. Cultural diversity and entrepreneurship: policy responses to immigrant entrepreneurs in Australia. Entrepreneurship and Regional Development (2012), p. 2-6

[6] Dedadt J. For a More Effective Entrepreneur Ship Policy: Perception and Feedback as Precondictions. Reneontres de St. Gall (2014), p. 8-10.

[7] Hartd. The Emergence of Entrepreneur Ship Policy: Governance, Startups, and Growth in the US Knowledge Economy. Cambridge University Press (2013), p. 316-319

[8] Lundstrom, Anders and Stevenson, Lois. Entrepreneurship Policyaheory and practice. Springer (2015), p. 23-26 